\title{
POLITICISING ST. MARTIN AND CONSTRUCTING HERITAGE: A CASE STUDY OF A SMALL TOWN IN CROATIA
}

\author{
Juraj Belaj, Marijana Belaj, Petra Kelemen, Filomena Sirovica
}

\begin{abstract}
The article focuses on the processes of constructing and interpreting heritage and their use in legitimising ideological aims and creating a desired cultural identity of the town. Based on ethnographic records and accounts, newspaper and Internet sources, as well as recent archaeological investigations, the authors trace the positions attributed to St. Martin in the public (re)signifying of Dugo Selo, a small town in Croatia. They present St. Martin's gradual evolution from a saint on the margin of Communism through a local symbol associated with a broader national framework, towards a symbol of the pro-European orientation of the local community in the period when Croatia was politically approaching the European Union.
\end{abstract}

Keywords: construction, Croatia, Dugo Selo, heritage, politicisation, selection, St. Martin

\section{INTRODUCTION}

Based on the example of the use of St. Martin in Dugo Selo, a small town in northwestern Croatia, we trace the dynamics of the construction and interpretation of heritage aimed at creating a desired local identity. We observe these processes through three main sequences of the town's recent history, marked by political turbulence and changes in political orientation: through the period of the rule of Communist ideology, the period of gaining Croatia's independence, and the period marked by Croatia's preparations to join the European Union. The paper is based on the available ethnographic archival records covering the 20th century, newspaper records from the mid-20th century to the present, Internet resources, recent archaeological investigations, observations of contemporary public celebrations of St. Martin's Day, as well as interviews. In considering the positions attributed to St. Martin in the public (re)signifying of Dugo Selo, we are interested in the politics and selectivity of heritage. We consider the constructedness and processuality of the heritage and its embeddedness in 
a broader social and political environment to be incontrovertible. We therefore position ourselves alongside a number of research studies that, denying any naturalness, objectivity and self-evidence whatsoever of heritage and the identity built upon it, take interest in the agents performing the selection and search for contextual moments that foster the suppression and silencing of certain elements of culture, or their underscoring and transformation into a support pillar of local distinction and desired (tourist) attraction (see, e.g., Bendix 1989; Bruner 2005 [2004]; Hameršak \& Pleše \& Vukušić 2013; Handler \& Linnekin 1984; Kirshenblatt-Gimblett 1998; Timothy 2011). Following in those footsteps, we trace the way in which St. Martin has been treated in the public sphere of Dugo Selo: how his position at the margins of public imagery during the latter half of the 20th century shifted over the past twenty or so years to that of a prominent local symbol associated with a broader national framework and, lastly, what role he was awarded in the networking into European cultural landscapes during the period in which Croatia was drawing closer politically to the European Union.

\section{SETTING THE SCENE: DUGO SELO AND ST. MARTIN}

Dugo Selo is a small town lying some twenty kilometres east of Zagreb, gathering settlements at the foot of the hill called Martin Breg (206 m asl). The present population of the town numbers a little above ten thousand. The earliest written record about life in this area comes from the 1209 charter by Andrew II Arpad, King of Hungary and Croatia, which mentions the Land of St. Martin (“...terram sancti Martini...”), bestowed by the king upon the Order of the Knights Templar.

The rise of the administrative significance of Dugo Selo began in the mid-19th century when it became a district centre. In 1955, it gained municipal status, which it preserved throughout the next forty years, marked by Communist rule. In 1997, six years after Croatia had gained independence, its status was changed into that of a town.

Although St. Martin was the patron saint of the town from times immemorial, it was only in the last quarter of the 20th century that he became the lynchpin for the creation of the town's desired cultural identity. Apart from the town patronage, St. Martin is also the titular saint of a decrepit local church on Martin Breg, a hill above Dugo Selo, and by succession also the recent parish church in the centre of Dugo Selo.

The Roman Catholic parish of Dugo Selo is one of the five parishes in the City of Zagreb and the Zagreb County, and one of the 46 in Croatia that are 
dedicated to St. Martin the Bishop. St. Martin the Bishop, that is, St. Martin of Tours (Sanctus Martinus Turonensis) is considered the first saint worshipped in the western Christian tradition that did not die a martyr's death. He is one of the most popular saints in the West, recognised as the patron saint of France, of soldiers, horsemen and horses, smiths, weavers, tailors, winegrowers, shepherds, coopers, landlords, paupers, beggars, convicts, travellers, hoteliers, as well as domestic animals, geese in particular. In spite of the historical, geographical and cultural diversity of Croatia, the steadfast and rich veneration of this saint throughout the country is evident from the abundant hagiotopographic data, numerous ruins of earlier sanctuaries and the many older or younger churches dedicated to this saint, the literary heritage of St. Martin, as well as the celebration of his feast, Martinmas, the so-called Martinje (Zaradija Kiš 2004: 15-16). In Croatian popular piety, St. Martin is mostly associated with viticulture and wine. The ethnographic archival data collected in Croatia from the beginning of the 20th century until 1989 reveal that St. Martin as the patron saint of viticulture is venerated mostly in the western part of Croatia, including Dugo Selo. The Day of St. Martin is celebrated on November 11, when this saint ended his earthly life. Additional recently introduced reference to St. Martin in Dugo Selo calendar is July 4, the Summer Day of St. Martin, which commemorates Martin's appointment as a bishop in the year 371 (which will be discussed further on). In this area, the Feast of St. Martin on November 11 is marked by the custom of the baptism of wine, with St. Martin frequently being recognised as the one who baptises wine (see Belaj 2006: 142). The custom involves the baptism of must, which is then drunk to the enjoyment of the participants, all garnished by a banquet, the recurrent culinary peak of which is roast goose with mlinci, a type of popular homemade dough. The hedonistic character of this custom is probably the very cause for its spreading throughout Croatia at the end of the 20th century, even to places where St. Martin's feast had never figured as an important event in the past (Zaradija Kiš 2004: 107), as well as to places where throughout the entire 20th century patronage over vineyards and wine had been the prerogative of St. Vincent, for instance, in northern continental Croatia (Belaj 2006: 143).

Records from 20th-century Croatia indicate that St. Martin's role as a patron saint also encompassed other areas of life. For instance, he was known as the guardian of cattle, mainly in north-western Croatia. In the northern Croatian Littoral there are documented cases of his patronage of women in labour, of the dying, and of fields (ibid.: 91, 98, 140, 179, 181, 186, 188). During the 20th century St. Martin was remembered on his holiday as a marker in the agricultural annual cycle: this was the first day for the yearly slaughter of pigs and the day when horses were taken to the stables for the winter. This 
day marked the end of the agricultural year and the beginning of the winter quiescence (ibid.: 190, 262).

Although ethnographic archival data on the veneration of saints and celebrations of their feasts dating from the 20th century are rather sparse and meagre, they are a valuable source because they reveal areas of life that during the Communist period were by and large relegated to the private sphere.

\section{ON THE MARGINS OF COMMUNISM}

Based on the already mentioned archival data on the veneration of saints during the 20th century, St. Martin's main role in the Dugo Selo area was that of the patron of vineyards, whose feast was marked by the baptism of wine, a custom focusing on the transformation of must into young wine. This scant information about the Martinmas celebration in Dugo Selo, encompassing also the Communist period, is virtually the only evidence proving that the holiday was not entirely eradicated by Communist repression. During the 45 years of the Communist one-party system that Croatia experienced as part of the Socialist Federal Republic of Yugoslavia, St. Martin - just like all else of a religious nature - was marginalised and suppressed in public discourse. During that period the construction of the identity of Dugo Selo, same as all the other Yugoslav towns, was based on the Yugoslav socialist imagery, whose key topics were Josip Broz Tito, the People's Liberation Movement, and the Communist Party, which were inscribed into the names of streets and squares, into monuments, into the decoration of public institutions, local calendars and programmes of events, etc. In this infiltration of Yugoslav socialism into town life, the local newspapers played an indispensable role - in the case of Dugo Selo this was Dugoselska kronika (The Dugo Selo Chronicle), as the main local paper, published since 1967.

In that period the Dugoselska kronika followed the activities of the local administrative and political bodies and organisations, the Communist Party in particular, and celebrated the successes and memories of the People's Liberation Struggle during World War II, by following various dates from recent local (socialist) history. Particular attention was devoted to two events: the Battle of Oborovo, which took place on March 29, 1944, when 152 partisans were killed; and the Liberation Day of May 8, 1945, when partisan units entered Dugo Selo. The commemoration of these two dates played such an important role in the Dugo Selo calendar that they were successively chosen to mark the Municipal 
Day: the former in the 1970 s and the latter in the 1980s. It would appear that, beginning in the $1980 \mathrm{~s}$, the town was coming out of bereavement, increasingly associating the celebration in the narrower sense with a more cheerful concept (liberation), although the death of 152 people in Oborovo would continue to be commemorated to this day.

At the same time, during the Yugoslav Communist period, the Dugoselska kronika was mute as regards major Christian holidays, including Martinmas. Occasionally, but very rarely, St. Martin's Church on Martin Breg would figure, but invariably as a lifeless cultural-historical monument devoid of any religious attributes whatsoever. For instance, in an extensive article the author draws attention to the need to protect the church (see Crnić 1970: 4), while in another, which excellently underscores the spirit of the period, the unsigned author writes about the remains of the church with obvious caution and reserve:

It is entirely beside the point here that this is a church; this is irrelevant both for theism or atheism. [...] It is an entirely different question whether or not this edifice could or should have been spared from ruination and preserved for the 21st century. But this is not the subject of this text. (Martinska 1988: 12)

It is only with the beginning of the 1990s that texts about this church would start appearing with increasing frequency, to which we shall return later in the text.

Be that as it may, the inhabitants of Dugo Selo recount that during that period the Feast of St. Martin was nevertheless celebrated as the most important day - alongside Christmas and Easter - of the Dugo Selo parish. "St. Martin's Day was always celebrated with a liturgy," says the present-day parish priest, adding that the public celebration was strictly confined inside the church fence. Simultaneously, Martinmas was celebrated as the day of 'baptism' of young wine in the vineyard huts of the inhabitants of Dugo Selo. To be precise, on Martinmas or around that date the men would go to the vineyards to rack the must into clean barrels, and then they would 'baptise' the must with a bell and a prayer book: "St. Martin has arrived and arrived, he would baptise it, I would drink it" (Remenar 2013: 10). On those occasions they would invite each other to their huts, singing wine songs and feasting on sausages, bacon and cheese, while those more affluent would offer a goose with mlinci. These parties are reserved for men only, who would return to their homes in the morning to the toll of bells, announcing that "the must has been baptised". 


\section{EXTRACTION FROM OBLIVION}

The tide turned towards the end of the 1980s, just like in the rest of Eastern Europe. Croatia entered the period of multiparty democracy, which was soon followed by the dissolution of Yugoslavia and Croatia's independence. The beginning of the 1990s was a time of intense national enthusiasm, marked by the struggle to preserve independence in the Homeland War. Local papers of the period bear witness to the renewed interest of the community in national and religious topics. Religion was no longer considered 'dangerous', nor was the Church the 'enemy of the people' any more. What is more, religion and national identity were deemed to have been inextricably linked.

A full half year had gone by since the first multiparty election before, at the end of 1990, the local papers published two articles featuring life in the local church under the headings Kardinal posvetio novi oltar (Cardinal consecrates the new altar) (Gale 1990a: 3) and Koncert u župnoj crkvi (A concert in the parish church) (Gale 1990b: 5). As innocuous as the titles of these short texts may be, they would have been inconceivable in the paper's previous editorial policy. These two texts opened the newspaper space for local religious topics. From then on, the editorial board of the paper has never failed to mark Christian holidays with corresponding texts. Moreover, it has educated, or at least reminded local readers of the appropriate holiday adornment, providing recommendations of sorts as to "how to decorate the surroundings of their buildings" for Christmas holidays (Načinimo 1990: 12), pointing out that the "Christmas and New Year holidays are [...] an opportunity to recall the somewhat forgotten customs that had always been present in the Dugo Selo area" (Fotović 1990: 1).

Articles focusing on the old church of St. Martin on Martin Breg now started appearing with increasing frequency. They featured in almost every issue and were all written by the same journalist, Nenad Haleuš-Mali. Moreover, it appears that the church was increasingly materialising on the horizon of the local community. The titles themselves are evidence enough to perceive the increasingly more active and caring attitude towards the church: Što se poduzima da se Martinska crkva otrgne mraku propadanja: Radi se i razmišlja (What is being done to seize St. Martin's Church from the clutches of decay: Acting and thinking) (Haleuš-Mali 1991a: 8); Što kriju spisi (What are documents hiding) (1991b: 1); Pala lukovica tornja (The steeple dome collapses) (1991c: 1); Zaštita spomenika u ratnim uvjetima (Protection of monuments in war conditions) (1991d: 8); Rat spriječio radove: Zaštita Martinske crkve (War stops works: Protection of St. Martin's church) (1991e: 6); Nemila sudba dugoselske crkve (The tragic fate of the Dugo Selo church) (1992a: 7); Dočekali smo radove na Martinskoj crkvi (At long last the work starts on St. Martin's church) (1992b: 1); 
Skrb za svetoga Martina (Caring for St. Martin) (1992c: 8); Hoće li stati obnova sv. Martina (Is the reconstruction of St. Martin's about to halt) (1992d: 12); etc.

In 1991 the war events dominated the pages of the Dugoselska kronika. Military operations and the sharpening issue of refugees were burning topics that left no room for the culture of celebration, especially that of St. Martin's Day, which in that year was overshadowed by the fiercest fighting for the eastern Croatian town of Vukovar.

\section{MARTINISATION}

Martinmas earned a place in the Dugoselska kronika as late as 1992, but it did so in grand style. This was the first mention of the feast in the local paper that by then had been published for almost 25 years. In that first appeal to the Dugo Selo inhabitants to "celebrate St. Martin" it was mentioned that Martinmas had been celebrated in the area "for centuries", and that the "tradition was neglected during the past period" (Svetkovanje 1992: 1). According to the paper, the planned celebration of the feast included a three-day programme, whose mainstay was cultural and artistic performances based on the local folklore, and sports competitions between local clubs. The planned climax, that is, "the central act of the programme", was the "baptism of the must (according to age-old customs)" (ibid.). The same issue included visual and literary works by elementary school pupils from Dugo Selo with the old church on Martin Breg as the prevailing motif (see Žuta 1992: 7). And, finally, the entire last page of the paper featured a selection of excerpts from works by Dugo Selo writers, which, true enough, could only indirectly be associated with Martinmas. Even so, the editor of the article points out:

[---] looking at a broader picture, Martinmas is not just a day of the year, but much more - vineyards, vineyard huts, grapevines and labour around vines, all that begins in early spring and lasts until Martinmas. What is more, when we discuss the Dugo Selo area, this extends also to the church of St. Martin, which, in the words of the poet Slavko Vuric, is the 'complimentary guardian of our vineyard huts'. (Brajdić 1992: 12)

The title is given in the local dialect: Nikaj ni lepše nek v kleti biti, Martinje slavit $i$ moštek piti... (Nothing can match being in the vineyard hut, celebrating Martinmas and enjoying the must...), while in the introduction of the review the editor paints Martinmas as "one of those holidays and popular customs that are increasingly disappearing from the life of our towns and villages, in which the Dugo Selo area is no different from the rest" (ibid.). This prompted the editor 
to first provide a brief review of the customs associated with Martinmas, based on a very concise description of the customs in the villages north and south of Zagreb during the first half of the 20th century, written by ethnologist Ivanka Bakrač (see Bakrač 1988: 366-367). Apart from the fact that her description refers to the pre-Communist period, it should also be pointed out that although it might contain certain elements of the custom that were present also in Dugo Selo, the town itself and the surrounding area did not feature in the research by this ethnologist. Most excerpts from literary works chosen by the editor in fact contain no mention of St. Martin or Martinmas at all, but rather thematise the Dugo Selo landscape, scattered with vineyards and vineyard huts, as well as the chanting of wine songs and drinking of wine. Therefore, in this editorial interpretation St. Martin and Martinmas are equated with a much broader phenomenon, the culture of wine. The article contains also two songs inspired by St. Martin's Church and its environment, as well as the deterioration thereof. However, this selection of works by Dugo Selo writers includes two poems by a Dugo Selo poet, Milan Dobrovoljac Žmigavac (1879-1966), which directly thematise Martinmas, that is, details associated with this holiday. For instance, in the poem $K$ Martinju (Come Martinmas) the poet describes in humorous terms the forlorn and despondent ramble of geese around the courtyard in view of the impending arrival of Martinmas as their "judgement day", alluding to the custom by which a roast goose must adorn every table at Martinmas. The second poem of the same name celebrates the custom of the "baptism of the must" in vineyard huts, garnished by a plentiful feast, and the commotion that accompanies its preparation. However, this entire description is subordinated to the main emphasis of the poem, which is to point out this custom as an important determinant of Croatian national identity. The poet rhetorically asks himself:

Tko više štuje od nas Hrvatov

Toga patrona svih vinskih bratov?!

Who could be better than us, the Croats

in honouring this patron of all wine-lovers?!

He ends the poem with these verses:

Martina svetog koji ne štuje,

Taj na horvacke šege vam pluje,

Taj-o tom nema niti debate -

Nemre med prave spadat Hrvate!

Lack of respect for Martin the Saint, Is a spit in the eye of Croatian faith, 
He who does this - there is no doubt -

Could never and ever be a true Croat!

These verses at the same time mark the end of the editorial item. The alliance of the religious-customary and the national in a poem from a somewhat earlier time in history received a new welcome in this period of renewed awareness and resurrection of Croatian national identity, which at that time was, as a rule, equated with religious affiliation, namely with Catholicism. At the same time, this newspaper item as a whole heralded the triumphant return of St. Martin and Martinmas into the public life of Dugo Selo. From that moment on, the saint and his holiday would figure as the main elements in the process of the new symbolisation of Dugo Selo: a process that would be defined by terms such as the 'centennial tradition of St. Martin's', that is, by the alliance of the town, St. Martin's Church and Martin as the patron saint and the saint of wine, but also an alliance between the local and the national. In that vein, the editorial board of the Dugoselska kronika, in an article entitled Oživljen duh Martinja (The spirit of Martinmas reawakened), occupying the front page, reminds their fellow citizens that "St. Martin is the patron saint of Dugo Selo. He is the patron saint of the Dugo Selo parish and Martin Breg was named after him, together with its most beautiful landmark: the old church of St. Martin. To this one can also add vineyards and Martinmas" (Oživljen 1992: 1). The middle spread of the same issue featured an extensive report from the just completed threeday celebration of St. Martin's feast, describing the "renewed celebration of Martinmas", "the once traditional celebration of Dugo Selo", held "after many years", expressing the intention that these "traditional celebrations continue to be held in the future" (Da se nastavi 1992: 6). Unlike the above-mentioned announcement of the celebration, this report provides the first details about the celebration: it included an exhibition of books, publications and documents on Dugo Selo; an outdoor selling exhibition of domestic breads and cakes; passers-by were treated to a demonstration of the distillation of brandy (!) in an old cauldron, topped by tasting; traditional costumes were displayed; matches between local handball and football teams were organised; elementary school pupils held performances featuring St. Martin and Martinmas and, finally, a grand party was organised in the Croatian Army Centre. The party culminated with a performance of the "baptism of the must", with a 'bishop' and an 'acolyte', who 'baptised' a barrel of new wine with smoke from a censer. In the final words of the report, "[---] this was an unforgettable night in Dugo Selo [---] How could it not have been considering that 400 litres of freshly baptised must were drunk in the Croatian Army Centre?" (ibid.: 7) The celebration of Martinmas ended with a holy mass, which was "prepared and held in a particularly solemn manner" in the parish church of Dugo Selo, "teeming with the faithful" (Oživljen 1992: 1). 
A year later, the Feast of St. Martin was declared a municipal holiday by the decision of the Dugo Selo Municipal Council (Službeni 1993: 1). From then on Martinmas would be announced each year as the Municipal Day.

A clear illustration of just how great a momentum the process of "the resuscitation of St. Martin's spirit" has taken on in this period is provided by a newspaper article significantly titled Martinizacija (Martinisation), signed with the humorous pseudonym Martina Martinska. The text tells of how "the Spirit of St. Martin was reawakened like Aladdin, who accidentally surfaced to the light of day after a series of centuries spent inside a magic lamp. However, instead of serving his master, St. Martin's Spirit came to rule over us and our streets, taverns, houses - in short, over our Dugo Selo reality" (Martinska 1994: 12).

The author inventories the assets that came under Martin's portfolio, namely private companies, stores, guesthouses, galleries, a radio station, the Croatian Army Centre, an information guide through Dugo Selo with the surroundings, etc. The author found the Spirit of "St. Martin of Dugo Selo" and the "Martinisation trend" to be so assertive that she "feared", jokingly, of course, that Dugo Selo might change its name into Martin Grad (Martin Town). Yet, this was a lonely voice of resistance to the general Martinisation that was under way.

At that time, St. Martin was awarded a role in the celebration of the Statehood Day in Dugo Selo, which at the time was celebrated in spring, on May 30. Specifically for this occasion, the environment of the old church of St. Martin on Martin Breg was cleaned and decorated in order to host the manifestation precisely in that place. For the first time in 47 years, a mass was held there (in the open air), and the same day also saw the first exhibition of wines from the Dugo Selo and Vrbovec vineyards, as one of the main elements of the Martinmas image in the making (Povratak 1995: 6-7).

On the eve of the Martinmas of 1995, a 7-metre wooden statue of St. Martin, a work of the sculptor Josip Cikač, was erected near the church on Martin Breg. The article titled Nastavlja se svetomartinska povijest (The history of St. Martin's continues) casts Martin Breg with the new statue as a "pedestal to the venerated saint, the patron of our parish" and a "place that symbolises Dugo Selo and its surroundings". However, the statue was ascribed much broader meanings in addition to this local one. In the unveiling of the statue, art critic Juraj Baldani associated it with the Croatian national identity:

The tree is a symbol of our lands, a symbol of suppleness, [...] a symbol of growth, something that is unstoppable. Even if you cut it, it continues to grow. The Croatian people demonstrated their closeness with the tree. They wanted to cut us down, but we grow, like St. Martin has grown. For Croats the statue is, among other things, a symbol of freedom and all that we have today. 
At the ceremony, the then head of municipal government announced that the erection of the statue was only the beginning in the cultivation of Martin Breg, which would soon be followed by the reconstruction of the Martin Breg church (Nastavlja 1995: 1). The newly-erected statue would soon serve as a model for the creation of the Dugo Selo souvenir, ${ }^{1}$ and it also acquired a place in tourist brochures, for instance, in the following brief description of Dugo Selo:

An indelible mark upon the history and culture of this area has been imprinted by the name of St. Martin and by the Knights Templar. The oldest cultural and historic monument in Dugo Selo is the church of St. Martin [...] while at the foot of the church rises a $7 \mathrm{~m}$ tall wooden statue of St. Martin. A small version of it is an official souvenir of the town. (Dugo Selo 2011: 33)

When Dugo Selo was promoted to the status of a town, Martinmas ceased to be the Municipal Day and became the Town Day.

\section{A RETURN TO EUROPE}

The shaping of the identity of the town based on the tradition of St. Martin acquired a new dimension in the subsequent period, when certain new guidelines were added to the entire process. The 1995 announcement of the head of municipal government of Dugo Selo regarding the reconstruction of the Martin Breg church finally started materialising in this period. The town administration of Dugo Selo at that time initiated archaeological investigations as a precondition for reconstructing the church, and commissioned the Institute of Archaeology in Zagreb to carry out the excavation. The latter commenced the investigations in and around the Martin Breg church in 2002, under the leadership of one of the authors of this paper. From the present perspective and in the context of the topic of this article, we believe that this move by the town administration clearly reflects a change of policy of the town towards heritage, and the new plans the town has for that heritage. It is obvious that additional footholds were sought in the process of the further construction of the town's identity.

Before we proceed to briefly sketch the results of archaeological investigations relevant for the topic of this article, let us return to the already mentioned charter by King Andrew II Arpad from 1209. As we have noted, this is the oldest known written document about life in this area. By the charter the king granted the Land of St. Martin to the Knights Templar. The name of the granted land suggests that a church of St. Martin had already been there by that time. It is believed that the first church dedicated to St. Martin was erected 
at the time when Frankish missionaries were spreading Christianity in these lands (Buturac 1981: 15); since St. Martin was the patron saint of the Frankish kings and army, it is more than probable that it was precisely his cult that was used in Christianising the population. In addition to this, studies dealing with the reconstruction of the Slavic sacred landscape (J. Belaj 2009; V. Belaj \& J. Belaj 2014) have shown that in certain places St. Martin was deliberately chosen in the process of Christianising the Croats and Slavs, generally to supersede the supreme Slavic deity, Perun the Thunderer. Important for this process were those 'pagan' elements from St. Martin's biography that could facilitate the transition from the old religion to a new one for the Slavs (e.g. St. Martin's association with a millstone, the world of the dead, fires, wolves, bears, shepherds, his fight with the Devil, the fact that he rode a horse, etc.). The position of St. Martin's Church is special, with an open view to all the sides of the world. As the mentioned studies show, this is a holy place once 'inhabited' by Perun the Thunderer, which was concluded based on the spatial relationship with other positions with significant toponyms. Namely, one of the increasingly more numerous 'triangular' pre-Christian holy spaces - Martin Breg - Veleševec - Trebovec (ibid.) - is recognised in Dugo Selo.

After the Knights Templar, in 1314, the church on Martin Breg passed under the rule of the Knights Hospitaller. Both these knightly orders had their house (domus) on this extensive estate (preceptory of St. Martin). As the end of the Middle Ages drew nearer, the Hospitallers started to leave the lands, while Turkish incursions were becoming more frequent, bringing in a period of serious recession to the entire area. The old church was destroyed during these turbulent times. The core of the presently visible church was built in the latter half of the 15th century in Late Gothic style. Since then the church has been damaged and reconstructed a number of times. The great earthquake of 1880 dealt a final blow to it, and it was soon abandoned in its wake. The new church was built in the present-day centre of Dugo Selo, and it also bears the name of St. Martin.

The archaeological excavations at Martin Breg were conducted between 2002 and 2008. For the time being, they have shown that there are only rare finds from the pre-Templar phase of the church. For instance, one of the few finds bearing testimony to that phase of the church, and probably to the cemetery around it, is the jewellery of the local inhabitants from that time. The reason for the scant presence of finds from the pre-Templar horizon of the church primarily lies in the later intensive building activity at the site and, even more so, in the burials in and around the church extending far into the modern period.

The most eloquent sign of the presence of the Templars is the finding of a tombstone with a shield and sword carved in low relief. From the same period 
comes a silver Slavonian banovac coin, minted in Zagreb between 1310 and 1316 , as well as the large and expensive stone blocks built into the later phase of the church. The investigations also yielded the foundations of a Romanesque church, whose two-metre width speaks in favour of the assumption that the building was a church-fortress of the Templar Order. On top of the foundations of the Romanesque apse of the Templars, the Hospitallers later laid the foundations of their Gothic phase of the sanctuary, which at that time was polygonal with pillars. There are several portable finds from that period, when the Knights of Saint John ruled this estate. One of the two square rooms added to the church in the north yielded several coins of King Sigismund, and mid-15th-century pfennigs that had fallen behind the stone base of an altar. A burned context in the other room yielded a number of fragments of collapsed ceramic - unglazed stove tiles from the turn of the century, i.e., about 1500 . The remains are assumed to belong to a domus of the Hospitallers.

The majority of finds from both graves and layers belong to the modern period. These are again coins, followed by saintly medallions that often contain apotropaic inscriptions. Another common find is various small crosses that during the years of plague also assumed a protective role. Some graves yielded rosary beads - small silver symbols of Christ's passion inserted into a luxurious rosary. Other common modern-period finds are certainly buckles, buttons and similar accessories that were sewn onto clothes in which the deceased were buried.

The archaeological investigations were regularly covered by the local newspaper, which comes as no surprise since the town of Dugo Selo was not only the initiator but also co-financier of these investigations. Moreover, as was revealed soon, the assumed association of the church with the Order of the Knights Templar also became one of the mainstays in the creation of the town's desired identity. It was expected that the commissioned archaeological investigations would be the very means of the scholarly verification and evaluation of the connection of the Knights Templar with this area. Several years into the investigations, in 2007, the town administration initiated the publication of the results of the archaeological excavations, once again providing the financial wherewithal. Therewith, the original wish of the administration in Dugo Selo was to promote the presence of the Templars only, having no interest in the other results, since they did not fit in the image-building strategy of the town. Upon the insistence of the author - also a co-author of this paper - the topic of the book was eventually expanded. It finally became clear even to the town administration that the finds from the Templar period were too few for a book envisaged as a representative monograph of the Templar presence in this area. In the end, the book covered also the other results of the archaeo- 
logical investigations, and it was published under the title Templari $i$ ivanovci na zemlji svetoga Martina (Templars and Hospitallers on the Land of Saint Martin) (Belaj 2007).

Even so, in the Dugo Selo reinterpretations of the archaeological results only the history of the Knights Templar was exploited. All the more so, the 'Templar', youngsters dressed in "Templar uniforms, with equipment and recognisable insignia", were chosen to represent cultural tourism projects in Dugo Selo (publication of the book Templari $i$ ivanovci na zemlji svetoga Martina, the revitalisation of the central zone of Martin Breg, the forthcoming 800th anniversary of the mention of the Land of St. Martin) at the exhibition of the County Tourist Board within the International Tourism Fair held in Zagreb in 2007 (Kozić 2007: 1). The Templars performed a central role also in the exhibition days of the Templars in Dugo Selo, organised in 2010 on the premises of the Zagreb County Tourist Board. ${ }^{2}$ In the same vein, the Templars were the main motif of the events organised at the beginning of July, connected to the Summer Day of St. Martin, i.e., the day commemorating Martin's appointment as a bishop on July 4, 371. The events include a knight tournament, mediaeval cuisine, display of knightly equipment and crafts, children's Templar games and other activities. ${ }^{3}$ The ties with the Templars and the historical period are constructed by means of chronological coordinates of the Middle Ages (for instance, 'mediaeval cuisine', 'mediaeval customs') and precise temporal markers - performance of "delivering the charter by which, in 1209, King Andrew II of Croatia and Hungary granted the Land of St. Martin to the knights - Templars". ${ }^{4}$ Further historical foundation is construed by a spatial reference: the international knight tournament "is again taking place in the authentic historical location, below the old church of St. Martin". ${ }^{5}$ By chronologically and spatially anchoring the event, the Templars are placed into the historical spaces of Martin Breg and Dugo Selo, unambiguously guiding the participants to the key in which they can read the knights' equipment and scenes "at the same place, below the old church, where long ago convened the then owners of the 'Land of St. Martin', the Templars". ${ }^{6}$

The new interpretation of the history of Dugo Selo mentions that the Templars themselves chose the titular, St. Martin. As most Templars were French, they indeed frequently dedicated their churches to St. Martin, a bishop from Tours in France (Dobronić 1984a: 23; 1984b: 115), but in Dugo Selo it is often conveniently neglected that, as we have already stated, St. Martin had been present in these lands even before the arrival of the knightly orders. The rewriting of the history of Dugo Selo with two key motifs, St. Martin and the Templars, was aimed at forging intensive relations of the town's history with 
the broader European heritage. In this, from the perspective of Dugo Selo, the Templars and St. Martin were understood as pro-European symbols par excellence and, what is more, in synergy with each other.

The connection with the European heritage was confirmed in 2007, on the Summer Day of St. Martin. On that day the St. Martin Cultural Centre Croatia in collaboration with the European Cultural Centre of St. Martin of Tours and representatives of the town and the church, placed on the remains of the Martin Breg church a metal relief footprint of St. Martin. By this act Dugo Selo symbolically joined the network of many European places sharing the tradition of St. Martin in a European cultural itinerary "that follows the routes of St. Martin" (Grgić Ozimec 2007: 1). Furthermore, a map of European towns marked with the footprint of St. Martin was placed in front of the church. In addition to the many guests, the event was attended by the director of the European Cultural Centre of St. Martin of Tours, the French ambassador to Croatia, the Croatian ambassador to France, as well as the bishop of the Hungarian city of Szombathely, the birthplace of St. Martin according to a legend. The ceremony was accompanied by a costumed squad of 'Templars', and the guests were offered 'Templar biscuits' in the shape of the 'Templar shield', as well as 'Martin croissants' and 'Templis' wine.

A year before the accession of the Republic of Croatia to the European Union, on July 1, $2012^{7}$ (on the occasion of the Summer Day of St. Martin) a stone marker of St. Martin's Route was placed next to the church on Martin Breg, as part of another project of the mentioned Cultural Centres of St. Martin. The marker "conceived on the model of milestones from the 4th century, from the time of St. Martin", signifies the four cardinal directions, with an additional pointer in the direction of Tours. The pro-European orientation of this act was repeatedly accentuated in the commemorative speeches by a number of guests. For instance, the local parish priest, Slavko Kresonja, pointed out that St. Martin "17 centuries after his death manages to unite the peoples of Europe", while Ines Sabotič, the director of the St. Martin Cultural Centre (Croatia), stressed that "this was the first mark of the future pedestrian highway through which we shall set foot in Europe, and, vice versa, all in honour of the saint that unites us". "With this we symbolically return to where we belong - to Europe, to where we shall officially accede on this very day next year," said Ivan Gereci, Deputy Mayor of Dugo Selo (see Grgić Ozimec 2012: 11), on that occasion. The use of the European Union flag as a veil for the monument in the ceremony once again underscored St. Martin's role as the symbol of the pro-European orientation of the local community. 


\section{SAINT MARTIN: CONSTRUCTIONS AND INTERPRETATIONS}

St. Martin as a symbol offers various possibilities for interpretative constructions, facilitating his exploitation in legitimising ideological goals. It appears that the same had already happened upon his arrival in these lands with the Frankish missionaries in the 9th century. Since he was the patron saint of the Frankish kings and army, it is very likely that Frankish missionaries knowingly picked St. Martin in the process of the (re)Christianisation of these lands, using his special non-saintly features to suppress the pre-Christian Slavic cult of Perun. In time the 'pagan' traits of Martin's personality that he had brought with him from Gaul into our lands were gradually forgotten. The Christian values of this saint came to the fore. We can easily imagine him arriving like a soldier with a sword, riding a horse. As a historical person, he indeed was a soldier, and is often depicted with such iconography. Therefore, even though there are grounds for discussing the long history of harnessing St. Martin's symbolism for achieving specific aims, we focused our research on the recent decades and the construction of heritage in the name of recent political goals.

St. Martin, who was confined to the margins of the public sphere throughout the second half of the 20th century, was launched, in the wake of political changes, into the centre of local symbolisations. His feast started to be celebrated as the Day of the Municipality and, later on, that of the town, while the ceremonies, limited in the previous socialist period to the church precinct, started to feature rich and varied programmes. Besides, during the politically turbulent 1990s, the local characterisation by this saint started acquiring broader, national hues. Finally, during the period of Croatia's approaching the European Union, St. Martin evolved into a saint that "unites the peoples of Europe" and "brings Croatia back to where it belongs". In addition to these visible changes in the interpretation of St. Martin, and in the presence of the events associated with him in Dugo Selo, there is also the intention to materially inscribe the saint permanently into the landscape. On the one hand, by commissioning experts and providing financial support to the investigations, the town authorities have decided to incorporate the physical remains into the desired image of their town. On the other hand, new material symbols appear in the area: the seven-metrehigh wooden statue of St. Martin, the metal relief footprint of Saint Martin, the map of European St. Martin towns and the stone marker of St. Martin's Route. The physical remains of the past and the newly-placed signs thus become visible markers of the selected values and eloquently speak of the creation of the desired cultural identity. Highlighted in the local landscape, they are at the same time clearly connected with a European network, placing a small Croatian 
town on the European cultural map, at a time in which Croatia positions itself on the political map of the European Union.

The construction and interpretation of heritage as described by Hannam and Knox is a possible key to reading the intents of the Dugo Selo authorities. In their words, "heritage industry [---] is inherently about the telling of stories, and the association of those stories with historic sites, landscapes, artefacts and people" (Hannam \& Knox 2011 [2010]: 156). The story of the Land of St. Martin and the Templars, through the efforts of local authorities, is associated with the physical remains and new signs of 'St. Martin's heritage' that would bear witness to the European visibility of Dugo Selo. The local authorities came to the idea to enhance the process of equating present-day Dugo Selo, on the one hand, and St. Martin and the Templar Order on the other, by including experts whose investigations would serve to render the story connected with "historic sites, landscapes, artefacts and people" (ibid.) more convincing and more powerful. The moments in which St. Martin was positioned as a prominent saint of Dugo Selo in the past two decades were first connected with the local and national circumstances, and later also with the broader European framework. This confirms that under the influence of "contextual power relations" (ibid.: 152) meanings can be ascribed even to ostensibly clear and cold physical remains and that they, too, lend themselves well to various contemporary constructions and uses of heritage. These processes are marked by selectiveness and partiality, into which the discourse about the authenticity of historical sites is woven, which is further legitimised on the basis of scientific research; they are shown as changeable and sensitive to political and social circumstances. The temporal and spatial points of archaeological finds and the imagery of the Templars and St. Martin have been strategically harnessed to the creation of the desired image of the town.

\section{NOTES}

1 See the website of the Zagreb County Tourist Board: http://www.tzzz.hr/mjesta/dugoselo/crkva-na-bregu/, last accessed on March 3, 2015.

2 See the website of the Dugo Selo Tourist Board: http://www.tzds.hr/otvorena-izlozba$\% \mathrm{C} 2 \% \mathrm{ABdani}$-templara-u-dugom-selu\%C2\%BB/, last accessed on January 29, 2015.

${ }^{3}$ See the website of the Dugo Selo Tourist Board: http://www.tzds.hr/vitezovizelingradski-ozivjeli-srednji-vijek-u-dugom-selu/; http://www.tzds.hr/templari-usubotu-uspjeli-obraniti-svoju-utvrdu/, both last accessed on March 3, 2015.

4 See the website of the Dugo Selo Tourist Board: http://www.tzds.hr/vitezovizelingradski-ozivjeli-srednji-vijek-u-dugom-selu/, last accessed on January 29, 2015. 
5 See the website of the Dugo Selo Tourist Board: http://www.tzds.hr/medunarodniviteski-turnir-03-04-srpnja-2010/, last accessed on January 29, 2015.

6 See the website of the Dugo Selo Tourist Board: http://www.tzds.hr/templari-u-subotuuspjeli-obraniti-svoju-utvrdu/, last accessed on January 29, 2015.

7 The event took place on Sunday, July 1, because that year the Summer Day of St. Martin fell on a Wednesday, which was a working day.

\section{REFERENCES}

Bakrač, Ivanka 1988. Godišnji i radni običaji u okolici Zagreba. [Seasonal and Work Customs in Zagreb Surroundings.] In: Mario Petrić \& Marijan Sinković (eds.) Etnografska baština okolice Zagreba. [The Ethnographic Heritage of the Zagreb Surrounding Area.] Zagreb: Zadružna štampa, pp. 363-378.

Belaj, Juraj 2007. Templari i ivanovci na zemlji svetoga Martina. [The Knights Templar and the Knights of St. John on Saint Martin's Land.] Dugo Selo: Pučko otvoreno učilište Dugo Selo.

Belaj, Juraj 2009. Martin-Breg između poganstva i kršćanstva. [Martin-Breg between Paganism and Christianity.] Studia ethnologica Croatica, Vol. 21, No. 1, pp. 7999. Available at http://hrcak.srce.hr/search/?q=Martin-Breg+izme\%C4\%91u+pog anstva+i+kr\%C5\%A1\%C4\%87anstva, last accessed on January 29, 2015.

Belaj, Marijana 2006. Sveci zaštitnici u hrvatskoj pučkoj pobožnosti. [Patron Saints in Croatian Popular Religiosity.] Doctoral thesis. Zagreb: Sveučilište u Zagrebu, Filozofski fakultet.

Belaj, Vitomir \& Belaj, Juraj 2014. Sveti trokuti: Topografija hrvatske mitologije. [Sacred Triangles: Topography of Croatian Mythology.] Zagreb: Ibis grafika \& Institut za arheologiju \& Matica hrvatska. Available at http://www.academia. edu/8440508/Vitomir_Belaj_i_Juraj_Belaj_SVETI_TROKUTI._Topografija_ hrvatske_mitologije_Sacred_Triangles._Topography_of_Croatian_Mythology_O_ knjizi_About_book_, last accessed on January 29, 2015.

Bendix, Regina 1989. Tourism and Cultural Displays: Inventing Traditions for Whom? Journal of American Folklore, Vol. 102, No. 404, pp. 131-146. http://dx.doi. org/10.2307/540676.

Brajdić, Ivan 1992. Sveti Martin, Martinje i Martin breg u djelima dugoselskih pisaca. Nikaj ni lepše nek v kleti biti, Martinje slavit i moštek piti... [Saint Martin, Martinmas and Martin Breg in the works of writers from Dugo Selo. Nothing can match being in a vineyard hut, celebrating Martinmas and enjoying the must...] Dugoselska kronika, No. 330, p. 12.

Bruner, Edward M. 2005 [2004]. Culture on Tour: Ethnographies of Travel. Chicago \& London: The University of Chicago Press.

Buturac, Josip 1981. Božjakovina-Brckovljani 1209-1980: Iz povijesti župe, uprave $i$ gospoštije. [Božjakovina-Brckovljani 1209-1980: From the History of the Parish, Administration and Allodium.] Brckovljani \& Zagreb: Hrvatsko književno društvo sv. Ćirila i Metoda. 
Crnić, Ivica 1970. Biti ili ne biti - martinske crkve? [To Be or not to Be - for St. Martin's Church?] Dugoselska kronika, No. 32, p. 4.

Da se nastavi 1992 = Da se nastavi tradicija. [To Continue the Tradition.] Dugoselska kronika, No. 331, pp. 6-7.

Dobronić, Lelja 1984a. Viteški redovi: Templari i ivanovci u Hrvatskoj. [Knightly Orders: Templars and Hospitallers in Croatia.] Analecta Croatica Christiana, Vol. XVIII. Zagreb: Kršćanska sadašnjost.

Dobronić, Lelja 1984b. Posjedi i sjedišta templara, ivanovaca i sepulkralaca u Hrvatskoj. [Estates and Seats of the Knights Templar, Knights Hospitaller and Knights of the Holy Sepulchre in Croatia.] Rad JAZU 406. Zagreb: JAZU.

Dugo Selo 2011 = Dugo Selo: In the Spirit of St. Martin. Way to Croatia, No. 11, p. 33.

Fotović, Krešimir 1990. Dugoselski Božić. [Dugo Selo Christmas.] Dugoselska kronika, No. 310, p. 1.

Gale, Tomislav 1990a. Kardinal posvetio novi oltar. [Cardinal Consecrates a New Altar.] Dugoselska kronika, No. 309, p. 3.

Gale, Tomislav 1990b. Koncert u župnoj crkvi. [Concert in a Parish Church.] Dugoselska kronika, No. 309, p. 5.

Grgić Ozimec, Iva 2007. Otisak "stope sv. Martina" na staroj crkvi. [A Cast of "The Footprint of St. Martin' on the Old Church.] Dugoselska kronika, No. 493, p. 1.

Grgić Ozimec, Iva 2012. Dugom Selu prva oznaka svetomartinskog puta u Hrvatskoj. [Dugo Selo Marked as the First Croatian Site on the Route of St. Martin of Tours.] Dugoselska kronika, No. 555, p. 11.

Haleuš-Mali, Nenad 1991a. Što se poduzima da se Martinska crkva otrgne mraku propadanja: Radi se i razmišlja. [What Is Being Done to Seize St. Martin's Church from the Clutches of Decay: Acting and Thinking.] Dugoselska kronika, No. 316, p. 8.

Haleuš-Mali, Nenad 1991b. Što kriju spisi. [What Do Documents Hide.] Dugoselska kronika, No. 317, p. 1.

Haleuš-Mali, Nenad 1991c. Pala lukovica tornja. [The Steeple Dome Collapses.] Dugoselska kronika, No. 317, p. 1.

Haleuš-Mali, Nenad 1991d. Zaštita spomenika u ratnim uvjetima. [Protection of Monuments in War Conditions.] Dugoselska kronika, No. 318, p. 8.

Haleuš-Mali, Nenad 1991e. Rat spriječio radove: Zaštita Martinske crkve. [War Stops Works: Protection of St. Martin's Church.] Dugoselska kronika, No. 319, p. 6.

Haleuš-Mali, Nenad 1992a. Nemila sudba dugoselske crkve. [The Tragic Fate of the Dugo Selo Church.] Dugoselska kronika, No. 325, p. 7.

Haleuš-Mali, Nenad 1992b. Dočekali smo radove na Martinskoj crkvi. [At Long Last Work Starts on St. Martin's Church.] Dugoselska kronika, No. 326, p. 1.

Haleuš-Mali, Nenad 1992c. Skrb za svetoga Martina. [Caring for St. Martin.] Dugoselska kronika, No. 328, p. 8.

Haleuš-Mali, Nenad 1992d. Hocee li stati obnova sv. Martina. [Is the Reconstruction of St. Martin's about to Halt.] Dugoselska kronika, No. 329, p. 12.

Hameršak, Marijana \& Pleše, Iva \& Vukušić, Ana-Marija (eds.) 2013. Proizvodnja baštine: kritičke studije o nematerijalnoj kulturi. [Heritage Production: Critical Studies in Intangible Culture.] Zagreb: Institut za etnologiju i folkloristiku.

Handler, Richard \& Linnekin, Jocelyn 1984. Tradition, Genuine or Spurious. Journal of American Folklore, Vol. 97, No. 385, pp. 273-290. http://dx.doi.org/10.2307/540610. 
Hannam, Kevin \& Knox, Dan 2011 [2010]. Understanding Tourism: A Critical Introduction. London \& Thousand Oaks \& New Delhi \& Singapore: Sage Publications.

Kirshenblatt-Gimblett, Barbara 1998. Destination Culture: Tourism, Museums, and Heritage. Berkeley \& Los Angeles \& London: University of California Press.

Kozić, Nada 2007. Templari u kulturno-turističkim pohodima. [Templars in Cultural Tourism Campaigns.] Dugoselska kronika, No. 492, p. 1.

Martinska 1988 = Martinska crkva - smetlište. [St. Martin's Church: A Junkyard.] Dugoselska kronika, No. 284, p. 12.

Martinska, Martina 1994. Martinizacija. [Martinisation.] Dugoselska kronika, No. 338, p. 12.

Načinimo 1990 = Načinimo dugoselski božićni ugođaj. [Let Us Create the Dugo Selo Christmas Atmosphere.] Dugoselska kronika, No. 309, p. 12.

Nastavlja 1995 = Nastavlja se svetomartinska povijest. [The History of St. Martin's Continues.] Dugoselska kronika, No. 351, p. 1.

Oživljen 1992 = Oživljen duh Martinja. [The Spirit of Martinmas Reawakened.] Dugoselska kronika, No. 331, p. 1.

Povratak 1995 = Povratak Martin Bregu. [A Return to Martin Breg.] Dugoselska kronika, No. 348, pp. 6-7.

Remenar, Nevenka 2013. Priče mega detinstva: Martinje. [Stories of My Childhood: Martinmas.] Dugoselska kronika, No. 572, p. 10.

Službeni 1993 = Službeni glasnik općine Dugo Selo. [Official Gazette of Dugo Selo Municipality.] Dugoselska kronika, No. 337, p. 1.

Svetkovanje 1992 = Svetkovanje Svetog Martina. [Celebrating St. Martin.] Dugoselska kronika, No. 330, p. 1.

Timothy, Dallen J. 2011. Cultural Heritage and Tourism: An Introduction. Bristol \& Buffalo \& Toronto: Channel View Publications.

Zaradija Kiš, Antonija 2004. Sveti Martin: Kult sveca i njegova tradicija u Hrvatskoj. [Saint Martin: The Saint's Cult and its Tradition in Croatia.] Zagreb: Institut za etnologiju i folkloristiku.

Žuta 1992 = Žuta jesen i kruh svagdašnji: Radovi učenika Osnovne škole Dugo Selo. [Yellow Autumn and Daily Bread: Works by Pupils of Dugo Selo Elementary School.] Dugoselska kronika, No. 330, p. 7. 